\title{
Profitability and income analysis of a rice seed cultivation partnership
}

\author{
Amalia Ulpah*, and Enti Sirnawati \\ Indonesian Center for Agricultural Technology Assessment and Development, Jl. Tentara Pelajar 10, \\ Bogor, West Java, Indonesia
}

\begin{abstract}
The seed farming is a promising business that can be a solution to increase farmers' income. However, limited capital, narrow land, and limited human resources and technology often become obstacles for farmers, especially small farmers, in running their business. Partnership patterns between rice seed farmers and partner companies can be a solution to overcome these problems. This study aims to determine the effect of partnerships on the level of profitability and farmer income. The research was conducted in Subang Regency, Indonesia. Samples were taken as many as 50 rice seed farmers. The analysis carried out includes cost analysis, income and profitability analysis. The results showed that rice seed farmers who have partners are more profitable than farmers who are not partners. This can be seen from the value of the $\mathrm{R} / \mathrm{C}$ ratio in the farms of partner farmers, which is greater than that of non-partner farmers. Partner farmers have an $\mathrm{R} / \mathrm{C}$ value of 1,3 while non-partner farmers have an $\mathrm{R} / \mathrm{C}$ value of 1,14 . When viewed from an income perspective, the income of partner farmers is higher than that of non-partner farmers. The income of the partner farmers is IDR 8.803.095, - while the non-partner farmers' income is Rp. 4.154.691, -.
\end{abstract}

\section{Introduction}

The high number of Indonesia's population demands high quantity of rice. Fulfilling the rice cannot relysolely on imports, rather by extensification (increasing the production area) and intensification (technological improvements). However, extensification is difficult to do given the increasingly limited amount of land. Agricultural land is the type of land that has been converted the most, especially paddy fields [1] and then the opportunity to increase land area is very limited and the proportion of farmers' land ownership is getting narrower [2]. Therefore intensification is an option to increase rice production; on which by using a high quality seed. A high quality seed is one important element in farming that impact significantly on production. In farms pending, the cost for seed relatively small, only about 1-3 percent from the total farming cost production [3-5]. Using high quality seeds on rice production tends to be positive and significant increase the production. [68]. Therefore, the use of high quality can support the increased national rice production.

\footnotetext{
* Corresponding author: amaliaulpah@gmail.com
} 
Data from Seed directorate year 2015 shows that the use of qualified extension seeds has increased from the previous year. Trend in using certified rice seeds during 2010- 2015, comprise of the Direct Seed Assistance (BLBU), seed subsidies, National Seed Reserves $(\mathrm{CBN})$ and free market. During that period, there were terminations or reduction in BLBU in 2013 and 2014 that cause of high demand on the certified seeds in the free market [913]. This phenomenon indicates that certified seeds are highly demanding and promising business that motivates farmers to do a captive breeding.

The breeding of certified rice seeds in Indonesia is carried out by state-owned companies (PT Pertani and PT Shang Hyang Sri), seed centers, private or seed breeder farmer groups. The producers of these seed breeders range from level 1 (use simple or traditional method) to level 5 (has own R\&D and produces certified seeds). One of area having farmers' seed breeding business is Subang Regency, that also one of the largest rice production centers in West Java. Rice seeds from Subang Regency are in great demand by farmers from other regions. In running their farming, seed breeders require market guarantees for their products. In order to secure market and price guarantees, breeder farmers can form partnerships with seed producers. One of the largest private seed producers in Subang is CV Fiona Benih Mandiri (CV FBM). The company has earned certification from (BPSBTPH) and has a privilege as a distributor of stock seed gained the confidence to spread the seeds of staple (BP). CV FBM has been in partnership with local seed breeder farmers in Subang Regency since 2005.

The existence of a partnership pattern in the seed breeding business is expected to benefit and become a win win solution for both parties, especially farmers in. Through assistance in partnerships, farmers get the ease of providing inputs such as quality seeds, source capital for purchasing inputs, marketing their products, and intensive training and mentoring. Several studies have shown that partnerships will have a positive impact on farmers. Partnership make farmers are more efficient in using input [14-16]. Partnerships improve farmers' income [17-19]. The Partnership is expected increase farmers' production and ultimately increases income. Therefore, this study aims to determine the extend impact of partnerships in profitability and farmer income.

\section{Methods}

\subsection{Location, data obtain, and method data collection}

The research was conducted in Subang Regency, West Java Province. Four districts were selected purposively, namely:Pusakajaya, Pusakanegara, Ciasem, and Blanakan. The selection based on several considerations, including the largestrice production centers in West Java; farmer group already partnered with CV Fiona Benih Mandiri (FBM) - one of the largest rice seed companies in Subang with a total production of more than 5000 tons per year. Data were collected when farmers planted in the dry season and observed during the rainy season, from March to April 2018. The population were farmers who carried out captive breeding of rice seeds. The non probability sampling 50 samples divided into two categories (accidental sampling) : farmers who partner with CV Fiona Benih Mandiri and those who did not partner. The cross section data was collected by conducting direct interviews with farmers using a structured questionnaire. Primary data collected includes land area, use of inputs (seeds, fertilizers, pesticides, labor and other inputs), input and output prices, and production. Secondary data were obtained from government agencies such as the Ministry of Agriculture, and Indonesian Central Bureau of Statistics (BPS) of Subang, and Local Government. 


\subsection{Data analysis}

\subsubsection{Cost and income analysis}

Income analysis consists of calculating revenues and expenses. Farm income is the production value obtained from the total product multiplied by the selling price at the farm level [20]. The formula is as follows:

$$
T R i=Y i . P y i
$$

Tri : Total revenue

Yi : Production obtained

Pyi : Expenditure Price during the production process, which includes fixed and variable costs.

Fixed costs are defined as coststhat are relatively fixed in number and continue to be incurred even if the production is large or small. The amount of fixed costs does not depend on the size of the production obtained, for example land rent, taxes, and irrigation fees. Variable costs are dependent on the production obtained, for example, labor, seeds and fertilizers. The total cost can be formulated as follows:

TC : Total cost

$$
T C=F C+V C
$$

FC : Fixed costs

VC : Variable costs

Farming income is divided into income on all cash costs (cash income) and income on total costs (total income). The level of net cash income is the value of the product after deducting cash costs. While total incomeis the value of the product after deducting costs, either cash or calculated costs.

$$
\begin{aligned}
& \text { Icash }=N P-B T \\
& \text { Itotal }=N P-B T-B D
\end{aligned}
$$

Icash $=$ level of net cash income

Itotal $=$ level of total net income

$\mathrm{NP}=$ Product value (total output times price)

$\mathrm{BT}=$ Cash costs

$\mathrm{BD}=$ Costcalculated

\subsection{Profitability analysis}

Revenue-Cost analysis ( $\mathrm{R} / \mathrm{C}$ ratio) wasused to measure farming efficiency. The ( $\mathrm{R} / \mathrm{C}$ ratio) is the ratio between the gross revenue received from every rupiah spent in the production process. Mathematically, the $\mathrm{R} / \mathrm{C}$ ration formulated as follows:

$$
\begin{aligned}
& R / C \text { on cash costs }=\frac{\text { Total Revenue }}{\text { Total Cash Cost }} \\
& R / C \text { on total costs }=\frac{\text { Total Revenue }}{\text { Total Cost }}
\end{aligned}
$$

Furthermore, an analysis of the independent sample t-test, with a 95\% confidence interval, was carried out to determine whether there was a significant rice farming income differences between the cooperators and the non-cooperator farmers. The hypothes was:

$\mathrm{H}_{0}$ (initial hypothesis) $\quad: \mu_{1}=\mu_{2}$, no income differences between those categories $\mathrm{H}_{1}$ (alternative hypothesis) : $\mu_{1} \neq \mu_{2}$, there was income differences between those groups. The alternative hypothes is states that $\mu_{1}<\mu_{2}$ or $\mu_{1}>\mu_{2}$.

Number of two sample groups ( $\mathrm{n}_{1}$, cooperator and $\mathrm{n}_{2}$, non-cooperator) was the same, so the sample difference test formula usedwas the independent sample t-test separated variant as follows: 


$$
t=\frac{x_{1}-x_{2}}{\sqrt{\frac{52}{n 1}+\frac{5 \sqrt{2}}{n 2}}}
$$

Where:

$$
\begin{aligned}
& \mathrm{X}_{1}=\text { Sample average } 1\left[\frac{\sum X 1}{n}\right] \\
& \mathrm{X}_{2}=\text { Sample average } 2\left[\frac{\sum X 2}{\mathrm{n}}\right] \\
& \mathrm{S}^{2}=\text { Population variant } \\
& \mathrm{N}=\text { Number of data }
\end{aligned}
$$

The population variant $\left(\mathrm{S}^{2}\right)$ is calculated by the formula:

$$
S^{2}=\frac{\left[\sum x_{1}^{2}-\frac{\sum X_{1}^{2}}{\mathbb{N}_{1}}\right]+\left[\sum x_{2}^{2}-\frac{\sum X_{2}{ }^{2}}{\mathbb{N}_{2}}\right]}{\mathbb{N}_{1}+\mathbb{N}_{2}-2}
$$

Test Criteria:

a. If the $\mathrm{t}$-count $>\mathrm{t}$ table or a significant value $\leq 0.05$, Ho was rejected (accept H1); the difference was significant.

b. If the $\mathrm{t}$-count $\leq \mathrm{t}$ table or a significant value $>0.05$, Ho was accepted (reject H1); the difference was not significant.

Data analysis was carried out with the SPSS program. The results were analyzed and interpreted descriptively.

\section{Result and discussion}

\subsection{Cost analysis}

The cost structure in this study consists of cash costs and non-cash costs. The cash costs is the purchasing cost for inputs, consisting of seeds, fertilizers, pesticides, external labor costs, tractor machine rental costs, threshing machine rental costs, and irrigation costs.

\begin{tabular}{|c|c|c|c|c|}
\hline \multirow[b]{2}{*}{ Cost Components } & \multicolumn{2}{|c|}{ Partners Farmers } & \multicolumn{2}{|c|}{ Non Partner Farmers } \\
\hline & $\begin{array}{c}\text { Values } \\
\text { (IDR/acre) }\end{array}$ & $\begin{array}{c}\text { Cost } \\
\text { percentage } \\
(\%)\end{array}$ & Value (IDR/acre) & $\begin{array}{c}\text { Cost } \\
\text { percentage } \\
(\%)\end{array}$ \\
\hline \multicolumn{5}{|l|}{ Cash Costs } \\
\hline a. Seeds & 244,260 & 1.33 & 182,573 & 0.89 \\
\hline b. Fertilizer & $1,631,144$ & 8.86 & $1,516,663$ & 7.42 \\
\hline c. Pesticide & $1,507,388$ & 8.18 & $1,631,657$ & 7.99 \\
\hline d. Labour & $8,019,597$ & 43.54 & $8,759,659$ & 42.88 \\
\hline e. Tractor rental & 991,636 & 5.38 & $1,001,143$ & 4.9 \\
\hline f. Power thresher rental & 871,636 & 4.73 & 995,429 & 4.87 \\
\hline g. Land annual rental & $4,828,571$ & 26.22 & $6,047,619$ & 29.6 \\
\hline h. Irrigation & 323,348 & 1.76 & 295,384 & 1.45 \\
\hline Total cash costs (B1) & $18,417,581$ & & $20,430,126$ & \\
\hline \multicolumn{5}{|l|}{ Non-cash costs } \\
\hline a. Calculated land rent & $9,685,688$ & 0.90 & $7,501,587$ & 0.88 \\
\hline b. Family labour & $1,010,099$ & 0.09 & 934,760 & 0.11 \\
\hline c. Tax & 109,922 & 0.01 & 118,092 & 0.01 \\
\hline Non-cash costs (B2) & $10,805,709$ & & $8,554,439$ & \\
\hline Total costs $(\mathrm{B} 1+\mathrm{B} 2)$ & $29,223,291$ & & $28,984,565$ & \\
\hline
\end{tabular}
Meanwhile, The non-cash cost comprise of household labor cost, tax costs, and land rental costs if the land is rented out. The cost structure of the partnered farmers and the nonpartners is presented in Table 1.

Table 1. Cost structure of rice seed farming from partner and not partner farmers in Subang Regency 2018 
The main farming costs incurred based on the cash-cost analys was a labor expenditure outside the family [4,5], on which reached 43.54 percent for the mitra and 42.88 perscent for the non-partner. The largest cost component in rice farming in Pringsewu Regency was labour cost reached more than $66 \%$ [21]. Thus, expenditure of labor take the largest component in Indonesia farming cost due to high utilization of human power, such as in planting and harvesting. Expenditures of the non-partner farmers for non-family were higher than those in the partner farmer because partner farmers did rent land. This action save the expenses considering the high land rental costs. In addition, one of the ways to minimize farming costs is to reduce outside labor'sused.

Furthur more, the second largest expenditure was land rental (26.22 percent in partner farmers and 29.6 percent in non-partner farmers). Farmers in the study location are common to renttheir land, given the decreasing amount of farming land and smaller possibility to get job outside farming because of the low education. The land-rental-cost at the research site averaged around 11 million per planting season, the fact that The rentalland-cost in West Java is higher than outside Java. However, the rental-land-costpercentage in the partner farmers was relatively low because they applied the sharing systemsothat the funds spent on land rent are not too large. This system was contrast with those in the non-partner farmers that cultivated their land or did not land rent.

Another major expense was for fertilizers and pesticides that reached 8.86 percent in the partner and 7. 42 percent in the non-partner. The largest fertilizer expenditure was for urea, reached 2-3 percent. Meanwhile only small number farmers used the NPK Mutiara fertilizer because it very expensive. In contrast, seed cost was the smallest expenses among all the cost components for both groups. The seed used around $15-25 \mathrm{~kg}$. Thus, for an efficient farming, farmers have to be aware used of labor, land rent, fertilizers, and pesticides.

The high cost of renting land is a problem for farmers in Subang, especially farmers along the northern coast, considering that most farmers cultivate other people's rice fields either by renting or sharing. The share system or profit sharing can be an alternative for farmers in running their farms, because farmers do not need to think about the cost of renting the land. Only the profit-sharing ratio needs to beconsidered. Many governmentowned lands have been used as alternatives, but not all of them can accommodate landless small farmers.

\subsection{Income and profitability analysis}

The income analysis comprises of income from cash and income total costs. The revenue obtained from rice seed breeding was multiplication between the production and the selling price (shown in Table 2). The analysis shown that the rice farming for both farmers' group was profitable, as accordance with the previous study by Bolwig et al. (2009) and Miyata et al. (2010) who shows that partnerships can increase farmers' income. The profits obtained by partner farmers based on total cost calculation was IDR 8,803, 095.00 and IDR $19,608,804.00$ based on cash cost calculation per cropping season. Land rent expenses was calculated in the cash costs for farmers who did rental. Meanwhile, farmers who did shared cost system, the land rental costs are included in non-cash costs. Thus, Non-partner farmers got profits at a total cost of IDR 4,154,691.00 and cash costs profit reached IDR $12,709,130.00$. Therefore, farming for both farmers' group reached economically efficient and it feasible to run because of the positive profit. 
Table 2. Analysis profitability and income of rice seed farming from partner and not partner farmers in Subang Regency 2018

\begin{tabular}{|l|r|r|}
\hline \multicolumn{1}{|c|}{ Components } & \multicolumn{1}{c|}{ Partner farmer } & \multicolumn{1}{c|}{ Not partnerfarmers } \\
\cline { 2 - 3 } & Value (IDR/acre) & Value (IDR/acre) \\
\hline Total Revenue & & 7,189 \\
\hline a. Production (kg) & 7,194 & 4,610 \\
\hline b. Selling price (IDR) & 5,286 & $33,139,256$ \\
\hline Total revenue (A) & $38,026,386$ & $20,430,126$ \\
\hline Farm Cost & & $8,554,439$ \\
\hline Total cash cost (B1) & $18,417,581$ & $28,984,565$ \\
\hline Total non-cash cost (B2) & $10,805,709$ & $12,709,130$ \\
\hline Total cost (B1+B2) & $29,223,291$ & $4,154,691$ \\
\hline Profit above cash cost (A-B1) & $19,608,804$ & 1.62 \\
\hline Profit above cash cost (A-C) & $8,803,095$ & 1.14 \\
\hline R/C values above cash costs (A/B1) & 2.06 & 1.3 \\
\hline R/C values above total costs (A/C) & & 1.0 \\
\hline
\end{tabular}

The income of partner farmers was relatively higher than those of non-partner farmers. This is due to the relatively higher output selling price received by the partner farmers. The farming income was from the amount produced, multiplied by the average prevailing price. So that the income is influenced by the level of production and the selling price, depending on the situation and conditions at that time such as Climate, weather, and import policies. The price of grain is valued at IDR 300 - IDR 400, higher than the market price for consumptive rice. The higher income earned by partner farmers compared to nonpartner farmers shows that partnerships can make farmers' income relatively more stable and even profitable [22] Partnership may create oppurtunities to the farmers to increase their farming productivity [23]. The success of farming was also measured by efficiency analysis.[24]. The $\mathrm{R} / \mathrm{C}$ analysis measure to what extent the rupiah used can provide a number of revenues. The higher the the $\mathrm{R} / \mathrm{C}$ ratio, the greater the profit obtained from each rupiah incurred. So, the higher the $\mathrm{R} / \mathrm{C}$ ratio, the better the income efficiency level. The results of the $\mathrm{R} / \mathrm{C}$ analysis showed that partner farmers are more profitable than non-partner farmers (2.06 for the non partner and1. 62 for the other group). Farmers who make partnerships have a higher level of profitability on the cast cost [25], while R/C value of the total cost for the partner farmers gained 1.30 and 1.14 for the other group. However, the $\mathrm{R} / \mathrm{C}$ value from cash costs is higher than those of total costs this latter includes expenses for land rent and labor in the family that are not actually paid by the farmer. This result also indicate that partner farmers are more efficient than non-partner farmers.

The results of t-test analysis on the breeder income level on total and cash costs showed that the comparison of partner and non-partnerfarmer was significantly different at $\alpha=$ 0.05 . The Sig. (2-tailed) value is 0.003 , smaller than the value of $\alpha=0.05(0.003<0.05)$, so the decision is rejected by Ho. This result conclude that farm income of the partnered and non-partnered farmers are significantly different and significant at the level of 95 percent confidence, both income on cash costs and on total costs, as well as the $\mathrm{R} / \mathrm{C}$ value. Result on the different test also showed different results and significant at the 95 percent confidence level. The value of Sig. (2tailed) is 0.029 (for cash costs) and 0.014 (for total costs) where this value is smaller than the value of $\alpha=0.05(0.029<0.05)$ and $(0.014$ $<0.05$ ), then the decisionis to reject Ho. It concluds that the $\mathrm{R} / \mathrm{C}$ for cash costs and total costs for partner and non-partner farmers is significantly different and significant at the 95 percent confidence level. In addition, The significantly different $\mathrm{R} / \mathrm{C}$ value shows that the ratio of revenue obtained by farmers from each rupiah spent in the production process differs between partner and non-partner farmers. Partner farmers have a higher $\mathrm{R} / \mathrm{C}$ value 
than non-partnerfarmers, or in other words, partner farmers are more efficient than nonpartner farmers because of the revenue. However, The $\mathrm{R} / \mathrm{C}$ value of 1.30 for partner farmers and 1.14 for non-partner farmers is still vulnerable to the risk of loss if there is a changé in input costs or a decrease in production. This is due to the high expenditure for land rent. This has impact on the profits earned and on the $\mathrm{R} / \mathrm{C}$ value.

The profits obtained by non-partnered farmers were still relatively small. According to the total costcalculation, benefits obtained still far from living properly. The promising seed production business has no impact yet on farmers prosperity. Therefore a solution is needed to anticipate these problems, for example by increasing the skills of farmer groups or farmer group associations in termof entrepreneurs so that their bargaining position will be higher. In addition, intensive counseling and assistance from the government and partner companies is absolutely necessary given the low level of education of farmers. Although partnerships may create opportunities to the farmers to increase their farming productivity. However, they still need facilitation or assistance from the government or local institutions especially in formulating the contract agreement.[23]. This makes a partnership can take place effevtively and provide benefits for both parties. Therefore, it is still necessary to educate the farmers. Frequency of meetings with the extension workers have an effect on the reduction of technical inefficiency, and with their help, the researchers were able to transfer knowledge to farmers so that they could make better decisions inimproving their productivity [26].

Although the income partner farmers was more profitable than not partner farmers, there were still farmers who do not do partnership. These is because farmers don't want to be bound by the rules set by partner companies, not all farmers have the opportunity to partner, and habits from generation to generation think that their business is quite profitable. Education had a positive and tangible effect on participation in partnerships [23]. Other factors that influence partnership are efficiency, price guarantess, income and market guarantees [27] Farmers tend to participate in CF to anticipate marketing risks. [28]

\section{Conclusion}

The income and the $\mathrm{R} / \mathrm{C}$ ratio of partner farmers is higher than that of non- partner farmers. The $\mathrm{R} / \mathrm{C}$ Value of the cash crops indicate that the farm breeding for both groups was efficient. However, the $\mathrm{R} / \mathrm{C}$ value for the total cost showed that farmers are at risk of experiencing loses if there was à chance in input cost or a decrease a production. It was also indicated that the partnership has been efficient in economy but has not been able to maximum benefiting farmers in the maximum. Some causes were narrow cultivating land and minimum training.

\section{References}

1. M. J. Iskandar and Jamhari, Agraris. 6(2), 154-167 (2020).

2. S. Hery Susilowati and M. Maulana, Analisis Kebijakan Pertanian. 10(1) 17-30 (2016).

3. E. Puspitawati. Analisis kemitraan antara PT Pertani (Persero) dengan petani penangkar benih padi di Kabupaten Karawang [tesis]. (IPB University, 2004).

4. J.C. Kilmanun.Analisis efisiensi teknis dan pendapatan usahatani padi di Kabupaten Kubu Raya Kalimantan Barat [tesis]. (IPB University, 2012)

5. N. Machmuddin, N.Kusnadi, Y. Syaukat, JIPI. 6(2), 145-161 (2017).

6. N. Tinaprilla, N. Kusnadi, B. Sanim, D.B. Hakim, J. Agr. 7(1), 15-34 (2013).

7. N. Kusnadi, N. Tinaprilla, Susilowati, and Purwoto, JAE. 29(1), 25-48 (2011). 
8. F. Kasryno,P.Simatupang, E. Pasandaran, S. Adiningsih, FAE.19,2 pp. 1-26 (2001).

9. Directorate of seed. Annual Report 2012 Directorate of Food Crop Seed.(Ministry of Agriculture, 2012).

10. Directorate of seed. Annual Report 2013 Directorate of Food Crop Seed. (Ministry of Agriculture, 2013).

11. Directorate of seed. Annual Report 2014 Directorate of Food Crop Seed. (Ministry of Agriculture, 2014).

12. Directorate of seed. Annual Report 2015 Directorate of Food Crop Seed. (Ministry of Agriculture, 2015).

13. Directorate of seed. Annual Report 2016 Directorate of Food Crop Seed. (Ministry of Agriculture, 2016).

14. Hamidi H. Keterkaitan antara pelaku dan dampak kemitraan dalam agribisnis tembakau virginia di Pulau Lombok Nusa Tenggara Barat [disertasi]. (Gajah Mada University, 2008).

15. Y. Saigenji. Contract farming and its impact on production efficiency and rural household income in the Vietnamese Tea Sector [Disertasi]. (University of Hohenheim, 2010).

16. B. Sulistyo. Analisis pengaruh kemitraan terhadap efisiensi penggunaan faktor produksi dan pendapatan usahatani ubikayu (Kasus Kemitraan di PT. Great Giant Pineapple Kecamatan Terbanggi Besar Kabupaten Lampung Tengah [Skripsi]. (IPB University, 2004).

17. S. Bolwig, P. Gibbon,S. Jones, Word Dev. J. 37(6), 1094-1104 (2009).

18. S. Miyata, Minot N, Hu D., Word Dev. J. 37(11), 1781-1790 (2009).

19. M.A. Fitri, R. Afrizal, and Yuliandri, JACE. 1(1), 28-37 (2018).

20. Soekartawi, A. Soeharjo, J.L. Dillon, J.B. Haedaker. Ilmu Usahatani dan Penelitian untuk perkembangan Petani Kecil. Universitas Indonesia (1986).

21. Zahara, R. Mawardi, and A. Irawati. Analisis Biaya, Pendapatan Dan Faktor-Faktor yang Berhubungan dengan Pendapatan Usahatani Padi Di Kabupaten Pringsewu in Prosiding Seminar Nasional Agroinovasi Spesifik Lokasi Untuk Ketahanan Pangan pada Era Masyarakat Ekonomi ASEAN. 19-20 Oktober 2016. Bandar Lampung, Indonesia. (2017).

22. Sarwanto. Kemitraan, produksi, dan pendapatan peternak rakyat ayam ras pedaging (Studi Kasus di Kabupaten Karanganyar dan Sukoharjo) [tesis]. IPB University (2004).

23. A.Fitri, Harianto and R. WinandiAsmarantaka, J.M. Agr. 15(1), 12-22 (2018).

24. A.Soeharjo and Patong. Sendi-Sendi Pokok Usahatani. (IPB University, 1977).

25. S.Naim, L.A. Sasongko, and E.D. Nurjayanti, J. Mediagro.11(1), 47-59 (2015).

26. SO. Akinbode, Dipeolu AO, Ayinde I, AJARI. 6(28), 6027-6035 (2011).

27. D. Fidyansari, S.Hastuty, and I.K. Arianto, JP. 4, 2 (2016).

28. Rokhani, M. Rondhi, E. B. Kuntadi, J.M. Aji, A. Suwandari, A. Supriono, T.D. Hapsari, Agraris. 6(1), 12-23 (2020). 